Maria Stopa-Boryczka

\title{
ON THERMAL CHARACTERIS'TICS ANALYSIS OF CITY CLIMATES
}

From the several-part Atlas wspótzależności parametrów meteorologicznych $i$ geograficznych $w$ Polsce (Atlas of correlations of the meteorological and geographical parameters in Poland), published by our faculty, we present some aspects of using forms of statistical and geographical periodic changes in the city heat island in various spatial and time scales, made for Warsaw and other European cities (Stopa-Boryczka, Borczyka et al., 1994, 1995).

The first step was establishing and nominating tens of models there (months, seasons, half-year and year periods) - fourth degree regression polynomials, describing latitude, longitude and hypsometric variety of air temperature in Europe (and separately for Poland).

And so a new item entered empirical formulae - altitude above sea level (besides latitude and longitude). The value of average temperature is in $98 \%$ described by a fourth degree polynomial. Only $2 \%$ covers local factors, including anthropogenic ones. In special cases the following profiles are used as models: longitudinal, latitudinal, hypsometric air temperature and profiles of components of temperature field gradients (longitudinal, latitudinal, hypsometric) - Figs 1a, $1 b$.

Differences between the measured values and those calculated from the model are a way of showing the influence of local factors, including anthropogenic ones, on the climate (city heat island) - Tables 1a, 1b, Fig. 2.

The sinusoids graphs of annual regressions in air temperature changes (average daily, maximum, minimum, daily amplitude), set for several tens of stations located near larger cities, describe the warmest and coldest places (time of day and time of year) in Europe (and Poland).

The sinusoids graphs of annual regressions (periods of 365.25 days) in air temperature changes between the centre (as a solid) and surrounding, determine the most important thermal characteristics of a city - i.e. Warsaw. The sinusoid extremes indicate places, where the city heat island is most intensive, or disappears. The amplitudes of regression sinusoids of air temperature between development - condensed, relaxed, park greens and city surroundings show the share of type of area in shaping the city heat island - Fig. 3. 
Table 1a

Differences of air temperature $T_{i}-T_{\mathrm{obl}}$ between $T_{i}$ values and calculated by means of 4 th degree multinominal $T_{\text {obl }}$ in Europe - winter

\begin{tabular}{|l|r|r|r|r|r|r|}
\hline Location & \multicolumn{1}{|c|}{$T_{i}$} & \multicolumn{1}{c|}{$T_{0}$} & \multicolumn{1}{c|}{$T_{i}-T_{0}$} & & $\lambda$ & \multicolumn{1}{c|}{$H$} \\
\hline Murmansk & -10.1 & -9.595 & -0.50 & $68^{\circ} 58^{\prime} \mathrm{N}$ & $33^{\circ} 03^{\prime} \mathrm{E}$ & $46 \mathrm{~m}$ \\
Reykjavik & 0.1 & 0.469 & -0.37 & $64^{\circ} 08^{\prime} \mathrm{N}$ & $21^{\circ} 56^{\prime} \mathrm{W}$ & 16 \\
Aberdeen & 3.0 & 2.890 & 0.11 & $57^{\circ} 12^{\prime} \mathrm{N}$ & $01^{\circ} 12^{\prime} \mathrm{W}$ & 59 \\
London & 4.6 & 5.012 & -0.41 & $51^{\circ} 47^{\prime} \mathrm{N}$ & $0^{\circ} 32^{\prime} \mathrm{W}$ & 5 \\
Dublin & 4.9 & 5.059 & -0.16 & $53^{\circ} 26^{\prime} \mathrm{N}$ & $06^{\circ} 15^{\prime} \mathrm{W}$ & 81 \\
Oslo & -3.6 & -2.084 & -1.52 & $60^{\circ} 12^{\prime} \mathrm{N}$ & $11^{\circ} 05^{\prime} \mathrm{E}$ & 203 \\
Stockholm & -2.0 & -3.366 & 1.37 & $59^{\circ} 21^{\prime} \mathrm{N}$ & $17^{\circ} 57^{\prime} \mathrm{E}$ & 11 \\
Paris & 3.9 & 4.585 & -0.68 & $48^{\circ} 58^{\prime} \mathrm{N}$ & $02^{\circ} 27^{\prime} \mathrm{E}$ & 53 \\
Brussels & 2.7 & 2.908 & -0.21 & $50^{\circ} 48^{\prime} \mathrm{N}$ & $04^{\circ} 21^{\prime} \mathrm{E}$ & 104 \\
Zurich & -0.2 & -0.454 & 0.25 & $47^{\circ} 23^{\prime} \mathrm{N}$ & $08^{\circ} 34^{\prime} \mathrm{E}$ & 569 \\
Helsinki & -5.1 & -6.471 & 1.37 & $60^{\circ} 19^{\prime} \mathrm{N}$ & $24^{\circ} 58^{\prime} \mathrm{E}$ & 58 \\
Prague & -1.7 & -1.485 & 0.22 & $50^{\circ} 06^{\prime} \mathrm{N}$ & $14^{\circ} 177^{\prime} \mathrm{E}$ & 374 \\
Budapest & 0.5 & 0.824 & -0.32 & $47^{\circ} 31^{\prime} \mathrm{N}$ & $19^{\circ} 02^{\prime} \mathrm{E}$ & 130 \\
Bucharest & -1.0 & 1.987 & -2.99 & $44^{\circ} 25^{\prime} \mathrm{N}$ & $26^{\circ} 08^{\prime} \mathrm{E}$ & 82 \\
Sofia & -0.2 & -0.122 & -0.08 & $42^{\circ} 49^{\prime} \mathrm{N}$ & $23^{\circ} 23^{\prime} \mathrm{E}$ & 588 \\
Belgrade & 1.3 & 2.634 & -1.33 & $44^{\circ} 48^{\prime} \mathrm{N}$ & $20^{\circ} 28^{\prime} \mathrm{E}$ & 132 \\
Athens & 10.1 & 8.006 & 2.09 & $37^{\circ} 97^{\prime} \mathrm{N}$ & $23^{\circ} 72^{\prime} \mathrm{E}$ & 107 \\
Lisbon & 11.3 & 11.19 & 0.11 & $38^{\circ} 46^{\prime} \mathrm{N}$ & $09^{\circ} 08^{\prime} \mathrm{W}$ & 110 \\
Madrid & 5.7 & 5.653 & 0.05 & $40^{\circ} 24^{\prime} \mathrm{N}$ & $03^{\circ} 41^{\prime} \mathrm{W}$ & 657 \\
Naples & 9.1 & 7.940 & 1.16 & $38^{\circ} 25^{\prime} \mathrm{N}$ & $21^{\circ} 73^{\prime} \mathrm{W}$ & 3 \\
Moscow & -8.7 & -9.671 & 0.97 & $55^{\circ} 45^{\prime} \mathrm{N}$ & $37^{\circ} 34^{\prime} \mathrm{E}$ & 156 \\
Odessa & -1.2 & -1.047 & -0.15 & $46^{\circ} 29^{\prime} \mathrm{N}$ & $30^{\circ} 38^{\prime} \mathrm{E}$ & 64 \\
Warsaw & -2.3 & -2.553 & -0.25 & $52^{\circ} 09^{\prime} \mathrm{N}$ & $20^{\circ} 58^{\prime} \mathrm{E}$ & 108 \\
\hline
\end{tabular}

Table $1 b$

Differences of air temperature $T_{i}-T_{\text {obl }}$ between $T_{i}$ values and calculated by means of 4 th degree multinominal Tobl in Europe - summer

\begin{tabular}{|l|c|c|r|l|c|c|r|}
\hline Location & $T_{i}$ & $T_{0}$ & $T_{i}-T_{0}$ & Location & $T_{i}$ & $T_{0}$ & \multicolumn{1}{|c|}{$T_{i}-T_{0}$} \\
\hline Murmansk & 11.5 & 12.536 & -1.04 & Budapest & 21.3 & 20.047 & 1.25 \\
Reykjavik & 10.7 & 10.747 & -0.05 & Bucharest & 22.3 & 22.420 & -0.12 \\
Aberdeen & 13.2 & 13.794 & -0.59 & Sofia & 20.3 & 19.629 & 0.67 \\
London & 16.9 & 16.417 & 0.48 & Belgrade & 21.7 & 21.343 & 0.36 \\
Dublin & 14.7 & 14.401 & 0.30 & Athens & 26.5 & 24.987 & 1.51 \\
Oslo & 16.0 & 14.269 & 1.73 & Lisbon & 21.6 & 21.018 & 0.58 \\
Stockholm & 16.4 & 15.288 & 1.11 & Madrid & 22.8 & 21.196 & 1.60 \\
Paris & 18.4 & 18.066 & 0.33 & Naples & 22.9 & 23.300 & -0.40 \\
Brussels & 17.2 & 17.314 & -0.11 & Moscow & 17.6 & 17.442 & 0.16 \\
Zurich & 16.8 & 16.792 & 0.01 & Odessa & 21.2 & 21.988 & -0.79 \\
Helsinki & 15.6 & 15.556 & 0.04 & Warsaw & 17.8 & 18.389 & -0.59 \\
Prague & 17.2 & 17.670 & -0.47 & & & & \\
\hline
\end{tabular}


Fig. 1a. Profiles of air temperature in

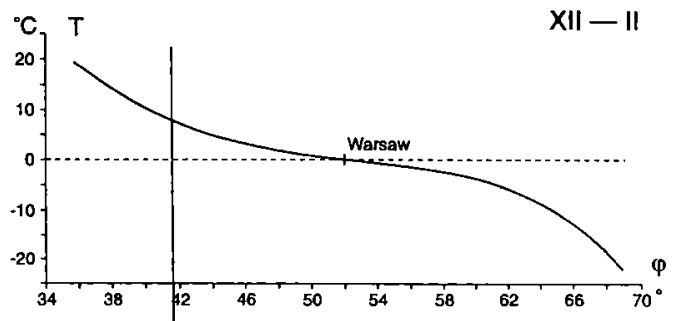

Europe: longitudinal $T(\phi)$, latitudinal $\mathrm{T}(\lambda)$ and hypsometric $T(H)$ - winter $T=146.9-0.0087 \phi-0.2935 \phi^{2}+$ $+0.0072 \phi^{3}-0.00005 \phi^{4}$

$T=4.724-0.3461^{1}-0.0057 \lambda^{2}+$ $+0.0006 \lambda^{3}-0.00001 \lambda^{4}$

$T=4.157-1.759 H-0.2003 H^{2}-$ $-0.0091 H^{3}+0.00013 H^{4}$

Fig. 1b. Profiles of air temperature in
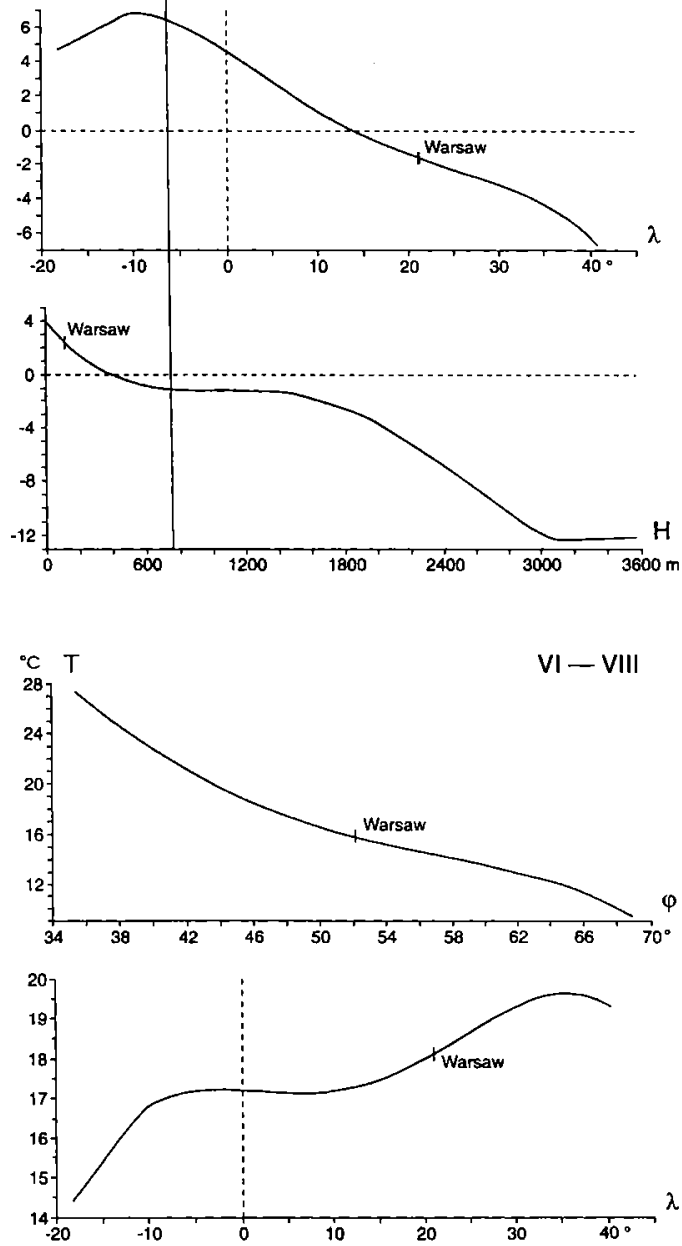

Europe: longitudinal $T(\varphi)$, latitudinal $T(\lambda)$ and hypsometric $T(H)$ - summer $T=71.9 \varphi-0.0027 \varphi-0.0908 \varphi^{2}+$ $+0.0020 \varphi^{3}-0.00001 \varphi^{4}$ $T=17.20-0.0127 \lambda-0.0014 \lambda^{2}+$ $+0.0003 \lambda^{3}-0.00001 \lambda^{4}$

$T=17.60+0.5702 H-0.1288 H^{2}+$ $+0.0051 \mathrm{H}^{3}-0.00007 H^{4}$

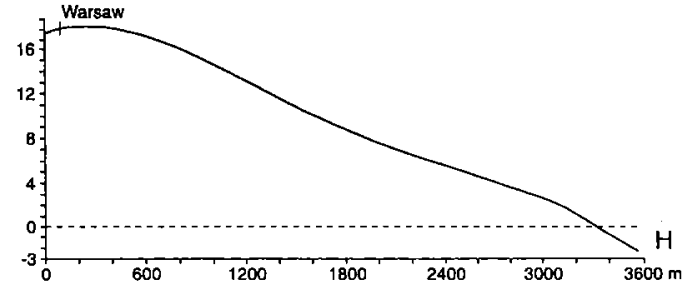




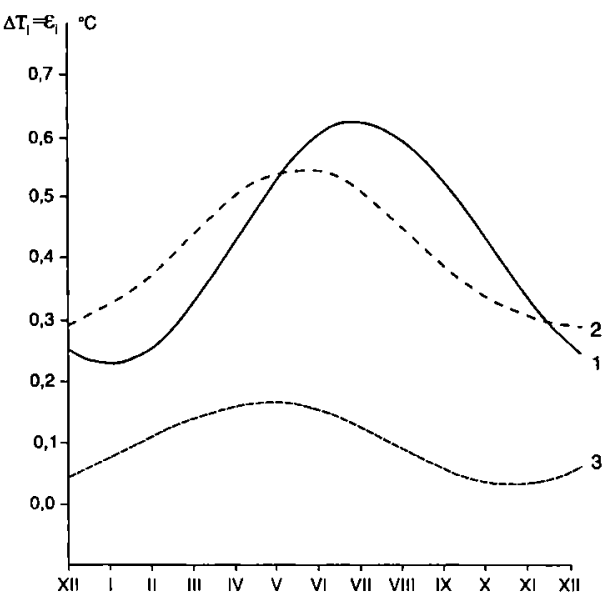

Fig. 2. Annual changes of differences of air temperature $\varepsilon_{\mathrm{i}}=T_{i}-F\left(\varphi_{\mathrm{i}}, \lambda_{\mathrm{i}}, H_{\mathrm{i}}\right)$ between measured $(T)$ values and calculated by means of 4th degree polynomial in Warsaw:

1 - Bielany (relaxed development),

2 - Obserwatorium (greens),

3 - Okęcie (suburbia)

The discussed works also mention relations between various methods of dependence and intensity (simple regression, regression parable, hyper-surface regression equations) of the city heat island to the state of the atmosphere - air temperature, wind speed and nebulosity. The influence of condensed and relaxed development and park greens is also discussed.
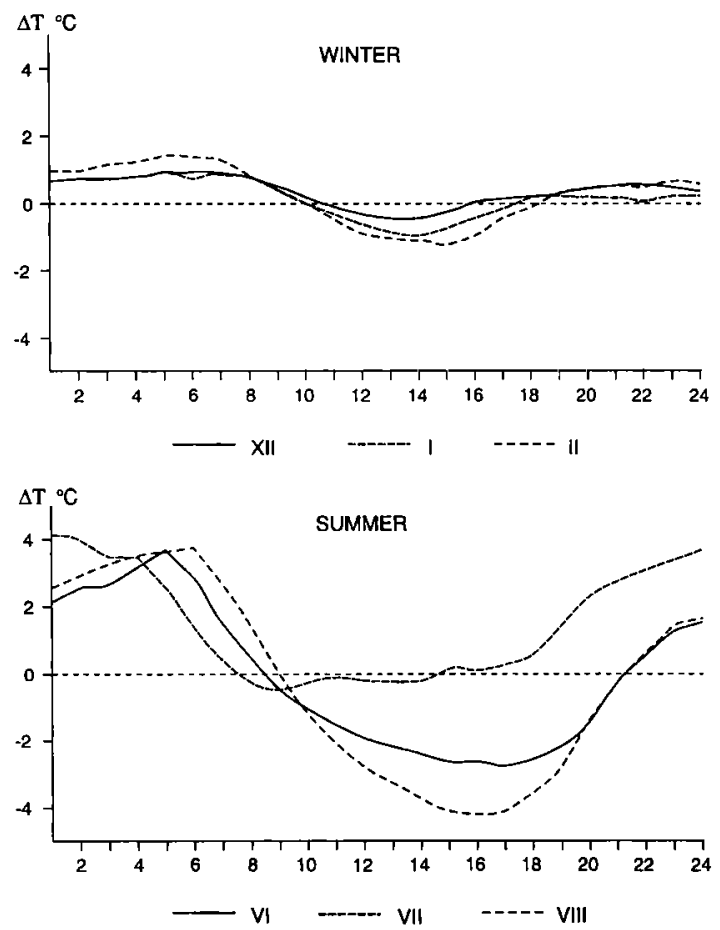

Fig. 3. The course of daily changes of air temperature differences $(\Delta T)$ between the centre and surroundings of Warsaw in winter (XII, I, II) and summer (VI, VII, VII) 1992. 
A significant methodological and practical influence is in the described two types of model tendencies of climate changes, based on long chronological air temperature sequences, atmospheric rainfall and atmospheric circulation in several European cities.

Prognostic models of the first type describe natural (periodic) climate changes with the distinction of the anthropogenic (line) factor. The natural factor is the resultant of overlapping real cycles - included in dense oscillation spectra. Second type prognostic models were achieved by developing meteorological variables into the Tyler sequence (according to the smallest squares) in relation to four most important parameters of the Solar System. These statistic models were used to create two types of similar convergent prognosis: so-called climatologic and astronomic tendencies for changes in climate in the 21st century - Fig. 4.

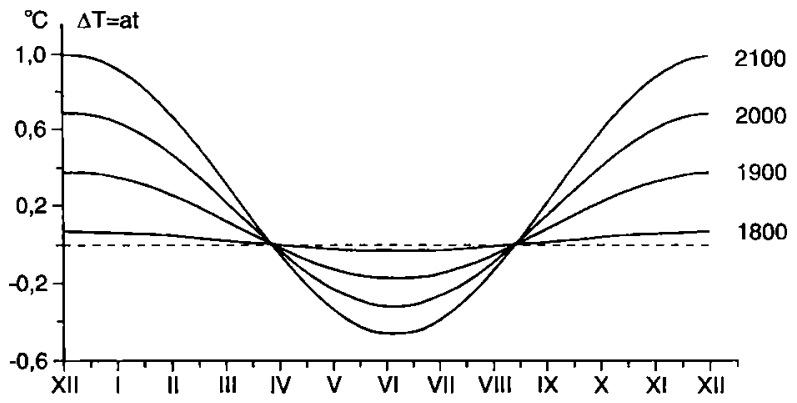

Fig. 4. Anthropogenic element $(\delta T=a t)$ of air temperature trend in Warsaw in the years: $1800,1900,2000,2100$ $a=0.0083+0.226 \sin$ $(2 \pi t / 365.25+1.494)$

$A=0.576+0.726 \sin$ $(2 \pi t / 365.25+1.252)$

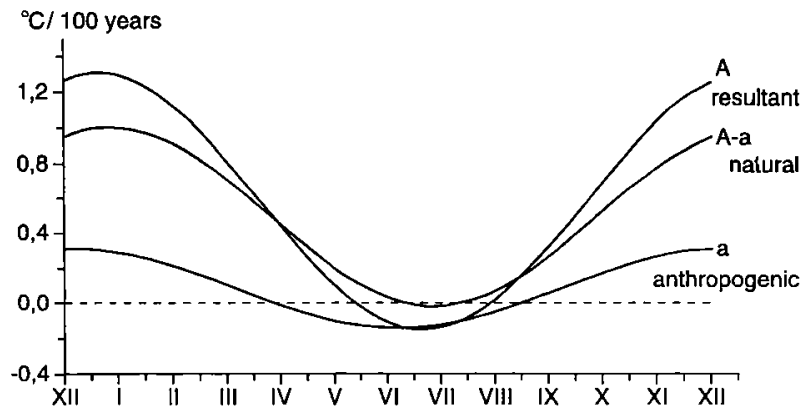

REFERENCES

Stopa-Boryczka M., Boryczka J., Wągrowska M., Śmiałkowski J., 1994, Atlas wspótzależności parametrów meteorologicznych i geograficznych $w$ Polsce (cz. VIII), Cechy oceaniczne klimatu Polski, (Atlas of correlations of the meteorological and geographical parameters in Poland. Part VIII. The oceanic features of the climate in Poland), Wyd. UW, Warszawa. 
Stopa-Boryczka M,. Boryczka J., Błażek E., Skrzypczuk J., 1995, Atlas wspótzaleźności parametrów meteorologicznych $i$ geograficznych w Polsce (cz. IX), Naturalne $i$ antropogeniczne zmiany klimatu Warszawy, (Atlas of correlations of the meteorological and geographical parameters in Poland. Part IX. Natural and anthropogenic changes in the climate in Warsaw), Wyd. UW, Warszawa. 